\title{
Tiziana Faitini*
}

\section{Shaping the Profession: Some Thoughts on Office, Duty, and the Moral Problematisation of Professional Activities in the Counter- Reformation}

\author{
https://doi.org/10.1515/jemc-2020-2017
}

\begin{abstract}
This paper investigates the theorisation of the duties belonging to different - both lay and professional - conditions, elaborated upon by postTridentine moral theology, in order to highlight its contribution to the modern conceptualisation of the profession, and, more generally, to modern economic and political rationality. It focuses particularly on how work and professional activities are dealt with in Juan Azor's Institutiones morales, Hermann Busenbaum's Medulla theologiae moralis and Alfonso de Liguori's Theologia moralis, between the early seventeenth and mid-eighteenth centuries. The paper begins with some quick historical remarks on the theological elaboration on the states of life (in the context of early-modern political and moral thought on duty and office) and the tradition de officiis underpinning these sources. The specific prescriptions imposed by these sources on professional activities in their discussions of the Third Commandment, and the obligation to rest or fast on certain days, are then examined. A brief analysis of the paragraphs explicitly devoted to the duties of professionals (legal and health professionals in particular) precedes some final observations about the post-Tridentine model of profession and its influence on the moral and socio-political valorisation of professional activities.
\end{abstract}

Keywords: post-Tridentine moral theology (17th-mid 18th centuries), work and profession, history of concepts, office (17th-mid 18th centuries), professional duties

\section{Introduction}

The concept of the profession is a complex, tightly woven fabric full of nuance; and its historical development clearly shows the mutual construction of juridical, religious and economic ideas and practices. According to Weber's famous

*Corresponding author: Tiziana Faitini, Max-Weber-Kolleg für kultur- und sozialwissenschaftliche Studien, Universität Erfurt, Erfurt, Germany, E-mail: tiziana.faitini@unitn.it 
interpretation, the Protestant elaboration of the Beruf - that is, the idea that any worldly activity is intrinsically also a calling or vocation - is fundamental both to the modern experience of the profession and to our economic rationality. ${ }^{1}$ Previously, however, other streams of thought had contributed to the emergence of our notion of the profession as having ethical, political, legal and economic value - and to the shaping of the figure of "the professional", which undoubtedly plays a leading role, and might even be seen as a prototype, in our neoliberal age. ${ }^{2}$

The Latin roots of this notion, indeed, help to explain the significance that has been accorded to professional activity - both manual and intellectual since the early-modern age; and the notion's importance as far as sociopolitical inclusion - and, conversely, sociopolitical exclusion - is concerned. Several elements belong to this less explored - and very complex - side of the concept of the profession, and establish the framework for our proposed analysis. of these, the experience of the doctores or professores within medieval universities is possibly the best known. Second, and perhaps less obvious, is the Roman juridical institution of the census and of the official declaration of one's property (the so-called professio census). This institution contributed to the shaping of the nexus between "profession" and belonging to an "order" (ordo), and had considerable influence on the conceptualisation of the professio monachi, i. e. the religious profession, which, in the Middle Ages, was the immediate referent for the concept of profession and very much affected its subsequent evolution. ${ }^{3}$

The early medieval monastery - a veritable laboratory of political, civil and economic rationality ${ }^{4}$ - is, indeed, a pivotal place in this regard. A monk's

1 See Max Weber, The Protestant Ethic and the Spirit of Capitalism, trans. Talcott Parsons (London: Routledge, 1992). For my purposes, echoing the definition given by Michel Foucault in his analysis on sexuality, experience needs to be understood as the correlation "of fields of knowledge, types of normativity and forms of subjectivity”. Michel Foucault, The History of Sexuality, vol. 2, The Use of Pleasure, trans. Robert Hurley (Harmondsworth: Penguin books, 1985), 4.

2 See the critical framework offered by Pierre Dardot, Christian Laval, The New Way of the World: On Neo-Liberal Society, trans. Gregory Elliott (London: Verso Book, 2014).

3 On the history of the concept of profession, see Tiziana Faitini, "The Latin roots of the 'profession'. Metamorphoses of the concept in law and theology from Ancient Rome to the Middle Ages," History of Political Thought 38/4 (2017): 603-22, and Ead., "Towards a spiritual empire. The Christian exegesis of the universal census at the time of Jesus' birth," in The Church and Empire, ed. Stewart J. Brown, Charlotte Methuen, and Andrew Spicer, Studies in Church History 54 (Cambridge: Cambridge University Press, 2018), 16-30.

4 See the illuminating insights offered by Peter Brown, The Ransom of the Soul. Afterlife and Wealth in Early Western Christianity (Harvard: Harvard University Press, 2018); Valentina Toneatto, Les Banquiers du Seigneur (Rennes: Presses Universitaires de Rennes, 2012); and Dilwyn Knox, "Disciplina. The Monastic and Clerical Origins of European Civility," in 
religious life officially began with the act of "profession", after which he became professor ordinis, belonging to a particular religious order and having a specific state of life (status vitae) within the ecclesiastical community. On the other hand, the central precept of the Benedictine rule - ora et labora - succinctly attests to the value accorded to work and professional activity (though, at the time, designated by the Latin words labor or ars rather than by the word professio) as an ascetic technique for monks. Sketchy as these references are, they help to indicate that the religious life and - crucially - the theological and juridical elaboration on the states of life which sprang from it, are key to any exploration of the modern valorisation of the profession, in which distinct semantic roots seem to have been intertwined. This paper, delving into a specific historical perspective, contributes to such an exploration and investigates the theorisation of the duties belonging to different - lay and professional - conditions or states of life, elaborated upon by post-Tridentine moral theology. A "Catholic countermelody" to Weber's Beruf is thus offered.

The paper focuses particularly on how work and professional activities are dealt with in Juan Azor's Institutiones morales, ${ }^{5}$ Hermann Busenbaum's Medulla theologiae moralis ${ }^{6}$ and Alfonso de Liguori's Theologia moralis, ${ }^{7}$ between the early seventeenth and mid-eighteenth centuries. It begins with some introductory, historical remarks on the theological elaboration on the states of life, on the tradition underpinning these sources, and on early-modern thought on duty and office (\$2). It then focuses on a number of specific prescriptions imposed by

Renaissance Society and Culture, ed. Ronald G. Musto and John Monfasani (New York: Italica, 1991), 107-36.

5 Juan Azor, Institutionum moralium in quibus universae quaestiones ad conscientiam recte aut prave factorum pertinentes breviter tractantur. Tomus primum [-tertium], 3 vols. (Cologne: Antonius Hierat, 1602-1612 [first published in Rome, 1600-1611]). On Juan Azor (1536-1603) see Johann Theiner, Die Entwicklung der Moraltheologie zur eigenständigen Disziplin (Regensburg: Pustet, 1970), 267-75; Andrzej F. Dziuba, "Juan Azor s.j. Teologo moralista del siglo XVI-XVII," Archivo teológico granadino 59 (1996): 145-55, and, on his methodology, the detailed account given by Stefania Tutino, Uncertainty in Post-Reformation Catholicism. A History of Probabilism (Oxford: Oxford University Press, 2018), 118-29.

6 Hermann Busenbaum, Medulla theologiae moralis (Monasterium Westphalicum: Bernardus Raesfeld, 1659 [first published in 1650]). An account of Hermann Busenbaum (1600-1668)'s life in Theiner, Die Entwicklung der Moraltheologie, 312-15; see also Jos. Brucker, "Busenbaum Hermann,” Dictionnaire de théologie catholique 2 (1910): 1266-68.

7 First published in Naples in 1748, and subsequently revised eight times in the author's lifetime. In what follows, I quote from the critical edition Theologia moralis, ed. Léonard Gaudé, 4 vols. (Rome: Typographia Vaticana, 1905). On the biography and moral theology of de' Liguori (1696-1787) see Marciano Vidal, La morale di S. Alfonso. Dal rigorismo alla benignità (Rome: Ed. Academiae Alphonsianae, 1992), with further references. 
these sources on professional activities in their discussion about the Third Commandment, and the obligations to rest and fast on certain days ( 33$)$. A brief analysis of the paragraphs which deal explicitly with the duties of lay professionals (§4) will precede some final observations about the post-Tridentine model of professions and the professionals, and its influence on the moral and socio-political valorisation of professional activities (§5).

\section{Arguing about office and the states of life: From the De officiis to the Institutiones morales}

Since late Antiquity, the ecclesiastical and the religious condition had been the objects of a detailed analysis which - building upon the legacy of both Stoic thought and the Roman juridical books "on the duties" of imperial officials ${ }^{8}$-, revealed the specific duties of different ministers and different roles. The treatises on the duties of Church ministers (ranging from Ambrose of Milan to Isidore of Seville to William Durand) give ample evidence of the depth of this analysis, ${ }^{9}$ as does the penitential literature which flourished in the Middle Ages. ${ }^{10}$ This tradition flowed into a theology of the states of life (status vitae), which distinguished three main different conditions: the religious, the clerical, and the lay condition. ${ }^{11}$

8 On the link between duty and role in Stoic thought, suffice it to recall Cicero, De officiis, I.27.93-94, and Seneca, De beneficiis, III.18, together with the observations by Maurice Testard, Introduction, in M. Tullius Cicéron, Les devoirs, ed. Maurice Testard (Paris: Les Belles Lettres, 1974), 7-92: 54-60; on the juridical books de officio see Aldo Dell'Oro, I libri de officio nella giurisprudenza romana (Milan: Giuffrè, 1960). An analysis of the Roman concept of officium can be found in Joseph Hellegouarc'h, Le vocabulaire latin des relations et des partis politiques sous la République (Paris: Les Belles Lettres, 1972), 152-70.

9 See Tiziana Faitini, Il lavoro come professione. Una storia della professionalità tra etica e politica (Rome: Aracne, 2016), 181-86, and Testard, Introduction, 67-68 for further references.

10 See at least Pierre Michaud-Quantin, Sommes de casuistique et manuels de confession au Moyen Âge (XIIe-XVIe siècles) (Leuven: Nauwelaerts, 1962); Handling Sin: Confession in the Middle Ages, ed. Peter Biller and Alastair J. Minnis (Rochester: York Medieval Press, 1998); and Joseph Goering, "The internal forum and the literature of penance and confession," in The History of Medieval Canon Law in the Classical Period, 1140-1234: From Gratian to the Decretals of Pope Gregory IX, ed. Wilfried Hartmann and Kenneth Pennington (Washington DC: Catholic University of America Press, 2008), 379-428.

11 On the historical process that led to the theological and juridical distinctions between the three states, mainly elaborated upon in the twelfth century, see Carlo Fantappiè, "Professio Status Contractus. Dal monachesimo antico agli ordini mendicanti," Politica e religione. 
From the thirteenth century onwards, mainly thanks to the activity of the Mendicant orders, the consideration of duties gradually extended to the lay condition; penitential texts, as well as moral literature, delve into these questions, providing in-depth descriptions of specific occasions of sins. ${ }^{12}$ A broader, increasingly detailed, spectrum of different social and professional categories was covered, from the married man or woman to farmers and physicians, from younger sons to merchants to jurists. This process was accelerated sharply by the Reformation and the Council of Trent. The Council indeed gave serious consideration to the lay community, and strict discipline was clearly imposed through the sacrament of penance. ${ }^{13}$ The need to comply with a rule of life, dictated by one's role and milieu, was disseminated throughout the ranks of lay society. Notoriously, this task was carried out mainly by the Jesuits, both in theory and in practice. ${ }^{14}$

Annuario di teologia politica (monographic issue: Censo, ceto, professione. Il censimento come problema teologico-politico) (2015): 193-228, at 211-17; Gaetano Lo Castro, Il mistero del diritto, vol. 2, Persona e diritto nella Chiesa (Turin: Giappichelli, 2011), 154ff. John Van Engen, "Professing Religion. From Liturgy to Law," Viator 29 (1998): 323-43. For an account of the theology of the states of life, see René Carpentier, "États de vie," Dictionnaire de spiritualité ascétique et mystique: doctrine et histoire 4/2 (1961): 1406-28, and René Carpentier, "Dévoir d'état," Dictionnaire de spiritualité 3 (1957): 672-702.

12 There was "an enlargement and a laicisation" of the monastic catalogue of vices and sins, as pointed out by Carla Casagrande and Silvana Vecchio, "La classificazione dei peccati tra settenario e decalogo. Teologia e pastorale (secc. XIII-XV)," Documenti e studi sulla tradizione filosofica medievale 5 (1994): 331-95, at 371. In addition to Goering, "The internal forum," see the classic Jacques Le Goff, "Métier et profession d'après les manuels de confesseurs au Moyen Âge," Miscellanea Mediaevalia 111 (1964): 40-60, and the informed overview given by Roberto Rusconi, L'ordine dei peccati. La confessione tra Medioevo ed età moderna (Bologna: Il Mulino, 2002), esp. 105-60.

13 See, among others, Adriano Prosperi, Tribunali della coscienza. Inquisitori, confessori, missionari (Turin: Einaudi, 1996); Paolo Prodi, Una storia della giustizia. Dal pluralismo dei fori al moderno dualismo tra coscienza e diritto (Bologna: Il Mulino, 2000). The centrality of the experience of confession in terms of social control and discipline has been widely explored: see e. g. Thomas N. Tentler, “The 'Summa' for Confessors as an Instrument of Social Control," in The Pursuit of Holiness in Late Medieval and Renaissance Religion. Papers from the University of Michigan Conference, ed. Heiko A. Oberman and Charles Trinkaus (Leiden: Brill, 1974), 103-37, and, from a genealogical perspective, Michel Foucault, Wrong-doing, Truth-telling. The Function of Avowal in Justice, trans. Stephen W. Sawyer (Chicago: Chicago University Press, 2014).

14 See the fresco painted by Louis Châtellier, The Europe of the Devout: The Catholic Reformation and the Formation of a New Society, trans. Jean Birrell (Cambridge: Cambridge University Press, 1989). On the relationship between the Catholic Reformation and the Jesuits, see the nuanced account given by John W. O'Malley, The First Jesuits (Harvard: Harvard University Press, 1993). The Jesuits, however, were not the only agents of the Tridentine reform: post-Tridentine bishops and their parish clergy were key actors in a comprehensive program of 
Within this context, the literature on the duties of the states of life blossomed. Besides sermons ${ }^{15}$ and treatises addressing specific professional conditions, ${ }^{16}$ the genre of the Institutiones morales was developed, to be used in the education of members of the religious orders and priests, particularly those training as confessors at Jesuit colleges. ${ }^{17}$ The Institutiones morales aim to be more detailed and complete than the summae confessorum of the Middle Ages and, at the same time, less theoretical and dogmatic than previous theological, Scholastic, literature. ${ }^{18}$ These encyclopaedic volumes are crowded with juridical and theological references, and specifically comment on the commandments of the Decalogue. ${ }^{19}$ A wide variety of topics are covered, ranging from the definition of moral law to commercial contracts, from the rules of marriage to the various duties of clergy and laymen, linked to their status and specific occupation. This genre reveals the birth of moral theology as an

social discipline, as pointed out by Wietse de Boer, The Conquest of the Soul: Confession, Discipline and Public Order in Counter-Reformation Milan (Leiden: Brill, 2001), 43-44.

15 Suffice it to recall the classic, inspiring analysis of Jesuit sermons made by Bernard Groethuysen, The Bourgeois. Catholicism vs. Capitalism in Eighteenth-Century France, trans. Mary Hilton (New York: Holt, 1968), which, whilst focusing on late seventeenth-eighteenth century France, provides deep insights into the development of a professional and economic morality, closely associated to the duties of the state of life.

16 See e. g. Marco Marcocchi, "Modelli professionali e itinerari di perfezione nella trattatistica sugli 'stati di vita'," in Lombardia borromaica Lombardia spagnola: 1554-1659, ed. Paolo Pissavino and Gianvittorio Signorotto (Rome: Bulzoni, 1995), 845-93.

17 Theiner, Die Entwicklung der Moraltheologie, 251ff; Louis Vereecke, Da Guglielmo d'Ockham a Sant'Alfonso de Liguori. Saggi di storia della teologia morale moderna 1330-1787 (Cinisello Balsamo: Ed. Paoline, 1990), 720-22. On the organisation of Jesuit colleges and the teaching of moral casuistry, O’ Malley, The First Jesuits, 144-46, and, in more detail, La «Ratio studionum». Modelli culturali e pratiche educative dei Gesuiti in Italia tra Cinque e Seicento, ed. Gian Paolo Brizzi (Rome: Bulzoni, 1981), in particular the essay by Giancarlo Angelozzi, "L'insegnamento dei casi di coscienza nella pratica educativa della Compagnia di Gesù,” at 121-62; The Jesuit Ratio Studiorum: 400th Anniversary Perspectives, ed. Vincent J. Duminuco (New York: Fordham University Press, 2000).

18 An explicit statement of this aim may be found in Vincenzo Figliucci's Moralium quaestionum de Christianis officiis et casibus conscientiae [...] tomi duo (Lyon: Jacques Cardon, 1634 [first published in 1622]). In the preface, he highlights the opportunity for a new equilibrium between the two traditions, by which "aut enim nimis ieiune et breviter Summistorum more doctrina traditur, aut nimis fuse et prolixe, scholastica plane ratione” (Figliucci, Moralium quaestionum, "Ad lectorem," no page number). On Figliucci's work, see Theiner, Die Entwicklung der Moraltheologie, 280-89.

19 On the increasing importance of the classification of sins according to the Decalogue, starting from the thirteenth century onwards, which culminated in the Council of Trent and its Catechism, see Philippe Delhaye, Le décalogue et sa place dans la morale chrétienne (Brussels-Paris: La Pensée catholique, 1963); John Bossy, "Moral Arithmetic. Seven Sins into Ten Commandments," in Conscience and Casuistry in Early Modern Europe, ed. Edmund Leites (Cambridge: Cambridge University Press, 1988), 214-34; Vecchio and Casagrande, La classificazione. 
autonomous discipline and attests to the increasing juridicization of morality through which the post-Tridentine Roman Church attempted to discipline the individual conscience and create a specific normative sphere. ${ }^{20}$

The impact of the genre is, of course, not limited to moral theology and the strictly religious dimension. The probabilistic method developed within it to deal with moral issues, traditionally interpreted as a way to justify moral laxism, was also a subtle approach to an era of profound change and dramatic conflict; this method had large epistemological and historical implications for the intellectual history of Europe in the early modern period. ${ }^{21}$ Moreover, the prominent role of the Jesuit colleges in the education of early modern European political elites - and more generally in the culture of the time -, and the activity of political counselling undertaken by confessors at the European courts up until the eighteenth century, meant that the influence of the genre concretely rippled out into the wider society. ${ }^{22}$

From among this enormous body of writing, two noteworthy Jesuit examples will be picked out and analysed in the next paragraphs: Juan Azor's Institutiones morales (1600-11) - the first work to bear this title - was widely read and appreciated for its new systematisation; Hermann Busenbaum's Medulla theologiae moralis (1650), which succinctly summarises and discusses the moral scholarship of the previous decades, found an even greater audience across Europe at least until the end of the following century. ${ }^{23}$ These texts will be compared to Alfonso de Liguori's Theologia moralis which - initially published

20 On this literature, see Vereecke, Saggi di storia della teologia; Theiner, Die Entwicklung der Moraltheologie; Miriam Turrini, La coscienza e le leggi. Morale e diritto nei testi per la confessione della prima Età moderna (Bologna: Il Mulino, 1991); Eduardo Moore, "Los jesuitas en la historia de la teología moral,” Studia Moralia 28 (1990): 223-45; Christiane Birr and Wim Decock (eds.), Recht und Moral in der Scholastik der Frühen Neuzeit 1500-1750 (Berlin-Boston: De GruyterOldenbourg, 2016), and the information collected in the database Scholasticon, ed. Jacob Schmutz, https://scholasticon.msh-lse.fr/ (accessed on 28.12.2019). Valuable insights to contextualise the debated questions, even if mainly with reference to the sixteenth century, are provided by Vincenzo Lavenia, L'infamia e il perdono. Tributi, pene e confessione nella teologia morale della prima età moderna (Bologna: Il Mulino, 2004).

21 See Tutino, Uncertainty in Post-Reformation Catholicism.

22 See, among others, Châtellier, The Europe of the Devout; on the Jesuits as a value-forming elite, A. Lynn Martin, The Jesuit Mind. The Mentality of an Elite in Early-Modern France (Ithaca: Cornell University Press, 1988), ch. 1-6, and, on the role of the confessors at the Royal Courts, Nicole Reinhardt, Voices of Conscience: Royal Confessors and Political Counsel in SeventeenthCentury Spain and France (Oxford: Oxford University Press, 2016).

23 Azor's Institutiones had 40 editions in 25 years; Busenbaum's Medulla went through more than 200 editions before 1776. See Dziuba, "Juan Azor," 151; Theiner, Die Entwicklung der Moraltheologie, 312; Moore, "Los jesuitas," 233-34 and 241. 
in 1748 as a commentary on Busenbaum's Medulla, and thoroughly revised by the author in a number of subsequent editions - condensed "the best of postTridentine moral thought" and was to become a milestone for modern moral theology. ${ }^{24}$

This provisional analysis, while far from providing an exhaustive view of the moral problematization of professional activities developed by the postTridentine moral theology, may nevertheless allow us a valuable insight into this subject, and paves the way for further research. It is hoped that it will also deepen our understanding of a pivotal moment in the intellectual history of the relationship between religion and politics, and, in particular, of the extent to which the Ciceronian and Christian accounts of office fed into early modern political and moral thought in Europe. As scholarship has argued, the polysemic rhetoric of office was ubiquitous at that time ${ }^{25}$ - or, more precisely, was still ubiquitous. Christian thought on the duties of life (and the corresponding ecclesiastical practice) mingled with classical concepts of service and public good in the concrete practice of officeholding in early modern European societies. The exercise of executive and judicial functions - essential forms of political participation in those days and, as is well known, crucial to the formation of the modern State and its bureaucracy - was profoundly - albeit in a differentiated, context-sensitive way - influenced by this mingled tradition. ${ }^{26}$ What follows will hopefully contribute to further support and extend this

24 Vidal, La morale di S. Alfonso, 147 (and at 69-106 for an account on the different editions). The work was first published as Medulla Theologiae moralis R. P. Hermanni Busenbaum cum adnotationibus per R. P. A. de Ligorio. In the second edition (Rome, 1753-1755), it was given the structure it retains, while the fifth edition (Bologna, 1763) no longer mentions Busenbaum's Medulla in the title. On Liguori's methodology as a compromise between radical probabilism and excessive rigorism, see the remarks in Tutino, Uncertainty in Post-Reformation Catholicism, 353-54.

25 Conal Condren, Argument and authority in Early Modern England (Cambridge: Cambridge University Press, 2006). On the genealogy of office, Giorgio Agamben, Opus Dei. An Archaeology of Duty (Stanford: Stanford University Press, 2013) provides some food for thought. However, as pointed out by Ian Hunter, “Giorgio Agamben's genealogy of office," European Journal of Cultural and Political Sociology 4/2 (2017): 166-99, Agamben's account is a Heideggerian allegory and a philosophical inquiry which cannot be read from a properly historical perspective.

26 The influence of the classical and ecclesiastical tradition of the officia on the formation of the modern State, from the Middle Ages onwards, has been explored from several point of view. In addition to Condren, Argument, see, among others, the overviews given by Gerhard Oestreich, Neostoicism and the Early Modern State, trans. David McLintock (Cambridge: Cambridge University Press, 1982), especially the final chapter, where the importance of Lipsius' and Neostoicism's attention to discipline, the education of the self and the reverent opinion of rulers and their office is insisted upon; Ernst-Wolfgang Böckenförde, "Zum 
claim from the less usual perspective of specific "offices", which, somewhat anachronistically, can be called "the professionals". ${ }^{27}$ When dealing with the rhetoric of office and the states of life, the continuity between the medieval and the early modern traditions must, in fact, be taken into account. ${ }^{28}$ At the same time, the transposition of this rhetoric (also) to the economic and professional sphere, which took place in the early modern period, will be highlighted.

\section{Professional activities in the commentary on the Third Commandment and the obligation of fasting}

Any attempt to understand how work and professional activities are conceptualised within religious traditions gains an interesting perspective from a discussion of the religious obligations of resting and fasting, obligations which are concretely and immediately related to everyday human needs and activities. It is no surprise that the religious definitions of work and leisure, permissible or

Verhältnis von Kirche und Moderner Welt,” in Reinhard Koselleck (ed.), Studien zum Beginn der modernen Welt (Stuttgart: Klett Cotta, 1977), 154-77; Gianfranco Miglio, "L’unità fondamentale della politica occidentale," in Id., Le regolarità della politica. Scritti scelti, raccolti e pubblicati dagli allievi, vol. 1 (Milan: Giuffré, 1988), 325-50; and Udo Wolter, "The Officium in Medieval Ecclesiastical Law as a Prototype of Modern Administration," in Legislation and Justice, ed. Antonio Padoa-Schioppa (Oxford: Clarendon, 1997), 17-36. See also the more historically situated analyses carried out by Mark Goldie, “The Unacknowledged Republic. Officeholding in Early Modern England," in Tim Harris (ed.), The Politics of the Excluded c. 1500-1850 (New York: Palgrave, 2001), 153-94; Michael J. Braddick, State Formation in Early Modern England c. 1550-1700 (Cambridge: Cambridge University Press, 2000); Dante Fedele, Naissance de la diplomatie moderne (XIIIe-XVIIe siècles). L'ambassadeur au croisement du droit, de l'éthique et de la politique (Baden-Baden: Nomos, 2017), 83-94 and passim.

27 According to the Oxford Dictionary (http://www.oed.com/view/Entry/152053?redirectedFrom= professional\#eid, accessed on 10.04.2019), the word "professional" was introduced into English as a noun in the mid-nineteenth century (the adjective was recorded with the modern meaning of "referring to an occupation" from the late eighteenth century onwards), and it is not possible to identify an exact Latin equivalent.

28 In addition to the classic Ernst H. Kantorowicz, The King's Two Bodies. A Study in Medieval Political Theology (Princeton: Princeton University Press 1997), see Frédérique Lachaud, L'éthique du pouvoir au Moyen-Âge. L'office dans la culture politique (Angleterre, vers 1150-vers 1330) (Paris: Garnier, 2010) and several remarks made by Janet Coleman, A History of Political Thought. From the Middle Ages to the Renaissance (Oxford: Blackwell 2000), especially 149-50 with reference to Marsilius of Padue. 
compatible activity are touched upon in interpretative debates about these obligations, either directly or indirectly.

In Christianity, the Third Commandment is the most obvious biblical reference to start with. The commandment states the duty to rest and abstain from work on holy days, and to make these days holy by attending a religious service. More precisely, its version in the Vulgate translation of the Bible specifies that “omne opus servile non facietis" (Leviticus 23:35), that is: "you shall do no servile work". ${ }^{29}$ Interpreters were thus confronted with the initial problem of defining "opus servile", in order to establish the activities permitted on holy days.

An old tradition (following Augustine in particular) gave a spiritualised, nonliteral, interpretation of the Third Commandment, stressing how it calls for prayer, the avoidance of sins and the contemplation of God; obviously, this approach contrasted with the Jewish interpretation of the Sabbath and its detailed classification of permissible activities. ${ }^{30}$ However, the question was also tackled by civil and canon law. The obligation to pause work and legal actions on Sundays was stated by Emperor Constantine, ${ }^{31}$ and some prescriptions concerning the prohibition of rural work, legal actions, public markets - were discussed in canon law from the sixth century onwards. ${ }^{32}$ These prescriptions

29 Biblia Sacra iuxta Vulgatam versionem (Stuttgart: Deutsche Bibelgesellschaft, 2007); trans. The Holy Bible, ed. Douay-Rheims (Baltimore: John Murphy Company, 1899). See also Exodus 20:8-10, Numbers 28:18 and 28:25.

30 On several occasions Augustine insists on this interpretation, e. g. in his Tractatum de decem chordis, 3 where he clearly states that "dicitur tibi ut spiritaliter observes sabbatum, non quomodo iudaei observant sabbatum carnali otio", in Sermones de vetere testamento, ed. Cyrille Lambot (Turnhout: Brepols, 1961), Sermo IX, 105-51, at 110. On Augustine's interpretation, see Carla Casagrande, "Astensione dalle opere servili e santificazione delle feste: il lavoro nell'esegesi del terzo precetto (secoli XIII-XIV)," in La grazia del lavoro. Atti del VII convegno storico di Greccio, ed. Alvaro Cacciotti and Maria Melli (Milan: Biblioteca francescana, 2010), 59-75, at 62-64, and, more generally, the historical account offered by Jean Gaillard, "Dimanche," Dictionnaire de spiritualité 3 (1957): 948-82, at 948-67, and Marcellinus Zalba, "De conceptu 'operis servilis'. Num crisi subiciendus et aetati nostrae attemperandus (I)," Periodica de re morali canonica liturgica 52 (1963): 149-163. On the concept of servile work during the Middle Ages, see Miguelangel A. De Espinal, "Nócion de obra servil en orden al descanso dominical,” Archivo teológico granadino 21 (1958): 5-197, and Id., “El 'opus servile’ en los franciscanos de la Edad Media," Laurentianum 1 (1960): 178-212, at 187f.

31 See the title De feriis in both the Theodosian and the Justinian Code (C.Th.2.8.1 and C.J. 3.12.2).

32 See $X 2.9$ (De feriis). Several councils dealt with this question: the prohibition of rural work was stated in 538 at the Third Council of Orleans; canon 15 of the Council of Rouen (around 650 $\mathrm{AD})$ was the first to use the expression "opus servile". See E. Dublanchy, "Dimanche," Dictionnaire de théologie catholique 4 (1911): 1308-48; Zalba, "De conceptu 'operis servilis'," 
were further elaborated within, and subsequent to, Scholasticism, and allowed a literal interpretation of the commandment. In this context, scholars examined all possible grounds for exemption from the obligations to rest and attend a religious service on certain days. A number of reasons linked to professional activities were gradually introduced, upon the basis of which exemption from these obligations was granted.

The same thing happened when the obligation of fasting on certain days was being scrutinised. Notwithstanding the efforts of early Christian authors to distance themselves from the legalism of Levitical proscriptions, the Church had invented its own detailed food rules, the most important of which was the Lenten fast. Fasting was, in fact, considered an essential part of Christian life; and, although theologians argued over traditional food restrictions in the Reformation period, they, regardless of their confession, were loath to abolish such restrictions altogether. ${ }^{33}$ From a Catholic perspective, grounds for exemptions were carefully explored, taking into account a person's particular activities and/or specific professional needs. In the cases of fasting and resting, very similar solutions were found. These explorations afford us remarkable insights into the understanding of professional activity and its duties, and therefore deserve some attention.

\subsection{Lucre in the definition of "servile work"}

As they dispute the definition of "servile work", a particular question captures the attention of the commentators on the Third Commandment: the link obviously grounded on classic philosophical dualism - between matter and servility, as opposed to that between spirit and freedom. From this perspective, the opposition between the free activity of the mind and the servile activity of the body, that is, between intellectual occupations and manual labour, is

145-49; Renato Coronelli, "Origine e sviluppo del precetto domenicale e festivo," Quaderni di diritto ecclesiale 18 (2005): 228-58.

33 On the basis of the precept of fasting and its historical development, see E. Vacandard, "Carême (Jeûne du)," Dictionnaire de théologie catholique 2 (1910): 1724-50; A. Thouvenin, "Jeûne," Dictionnaire de théologie catholique 8 (1924): 1411-17; Hermann-Joseph Sieben, "Jeûne," Dictionnaire de spiritualité 8 (1974): 1164-79. On the early modern period, see the overview offered by Ken Albala, "The Ideology of Fasting in the Reformation Era," in Food and Faith in Christian Culture, ed. Ken Albala and Trudy Eden (New York: Columbia University Press, 2011), 41-58; and Sylvio Hermann De Franceschi, Morales du carême. Essai sur les doctrines du jeûne et de l'abstinence dans le catholicisme latin (XVII-XIXe siècle) (Paris: Beauchesne, 2018). 
extensively discussed and gradated..$^{34}$ One particular aspect of this wide-ranging discussion seems more relevant from our perspective: the role played by lucre (lucrum). It would be challenging to precisely trace the evolution of the kind of labour the commentaries deem admissible on holy days from activities without monetary gain (sine lucro) to the possible implication of honest lucre (honestum lucrum) or, even later, of high or rare lucre (magnum/rarum lucrum). A specific form of "matter" was in question in this case, i. e. economic gain, which was held by an ancient tradition to be, in Cicero's words, the "pledge of servility" ("auctoramentum servitutis"). ${ }^{35}$ In this view, any money-making enterprise was, by its very nature, servile and even morally contemptible.

Notoriously, several Christian sources intertwined this classical heritage with the evangelical exhortation to poverty and ascetic renunciation, thus condemning the pursuit and possession of wealth and the undertaking of economic activity. This is clearly a complicated question. In fact, the relationship between Christianity and wealth cannot be considered one of a principled opposition which gradually slid into passive acceptance due to the failure of most believers to live up to Christian ascetic ideals and, later, the independent development of the market economy. As scholars have highlighted in recent years, Christian thinkers have been wrestling with the question of wealth distribution and the righteous administration of gain and economic exchange since the very beginning; new economic ideas and forms were, indeed, incubated behind monastery walls and within the Church. ${ }^{36}$ From the

34 In this regard, Thomas Aquinas is the obvious thinker to refer to: in interpreting the Third Commandment, he clearly states that intellectual activity was, as such, free and liberal, and allowed on holy days; while manual labour, if not required for the religious service, is servile and forbidden (Summa theologiae, IIa-IIae q. 122 a. 4 ad 3: "Est autem homo alterius servus non secundum mentem, sed secundum corpus [...]. Et ideo opera servilia, secundum hoc, dicuntur opera corporalia in quibus unus homo alteri servit"; a similar definition ibid., Ia-IIae q. 57 a. 3 ad 3). Azor explicitly observes that the distinction between intellectual and manual labour is not pertinent to the definition of servile/non-servile work (Azor, Institutionum moralium, pars II, lib. I, cap. XXVII, col. 171); nevertheless, among the relevant criteria when distinguishing between them, he also mentions the intensity of the physical effort and the materiality of the operations involved; these criteria are also stressed by Busenbaum (Medulla, lib. III, tr. III, dub. I, pp. 12627) and Liguori (Theologia, lib. III, tr. III, dub. I, n. 280 and 282, vol. 1, 554-56).

35 Cicero, De officiis, 1.150.42.

36 See Peter Brown, Through the Eye of a Needle. Wealth, the Fall of Rome, and the Making of Christianity in the West, 350-550 AD (Princeton: Princeton University Press, 2012), Giacomo Todeschini, Il prezzo della salvezza. Lessici medievali del pensiero economico (Rome: La Nuova Italia Scientifica, 1994), Paolo Evangelisti, Il pensiero economico nel Medioevo (Rome: Carocci, 2016). On the early modern period and our sources, see also the in-depth analysis carried out by Wim Decock, Theologians and Contract Law. The Moral Transformation of the Ius Commune (ca. 1500-1650) (Leiden: Brill, 2013). 
limited perspective of the medieval interpretation of the Third Commandment in the summae confessorum, nonetheless, the moral disqualification of lucre and, more precisely, the association between monetary gain and servility, are undeniable. ${ }^{37}$

This association gradually weakened, ${ }^{38}$ and the specific commentaries we are analysing bear clear witness to this nuanced process. When Azor discusses the possibility of writing (one of the traditional questions investigated, along with that of teaching) on holy days, he specifies that it is servile, and thus forbidden, to write for the sake of lucre: the activity is only allowed if its purpose is to extend one's own knowledge, or that of others, i. e. through teaching. ${ }^{39}$ However, he points out that this prescription arises from the dual nature material and intellectual - of the action of writing and adds that the simple fact of "aiming at lucre is not sufficient to make a liberal activity servile". ${ }^{40} \mathrm{~A}$ few lines below, a similar observation allows for the possibility of studying and teaching, and even being paid for these activities, since being done for the sake of lucre makes them only "minimally servile". ${ }^{41}$ On the one hand, therefore, while minimising its effects, he still implies that economic gain is a "servile factor", echoing previous, older traditions. On the other, by grounding the servility of writing in its dual nature, rather than in any resulting economic

37 It can still be traced within two well-disseminated examples published between the end of the fifteenth and the beginning of the sixteenth century: see Angelo Carletti of Chivasso, Summa angelica (Lyon: Antoine du Ry, 1520), art. Feriae, f. 88 v; and S. Mazzolini, Summa summaru[m] que Silvestrina nuncupatur, vol. 1 (Lyon: Joannes de Platea, 1520), art. "Dominica," q. IV, I, f. 188 v-189r. In this regard, both of them referred to the Franciscan Richard of Middletown (who flourished at the end of the thirteenth century): Super quatuor libros sententiarum Petri Lombardi quaestiones subtilissimae tomus tertius (Brescia: Vincenzo Sabbio, 1591), 1. III, dist. 37, art. 2 q. IV, p. 450. See the historical account given by Miguelangel A. de Espinal, "La intencion o 'finis operantis’ y las obras servil,” Revista Española de Derecho Canónico 13/39 (1958): 577-617; see also Dublanchy's ("Dimanche," 1321-24) and Zalba's ("De conceptu 'operis servilis'," 15456) observations.

38 In this regard, at the beginning of the sixteenth century Thomas de Vio Cajetan, commenting on Aquinas's discussion, is already striking for its clarity: "spes lucri non reddit opus ex non-servili servile”. In Thomas Aquinas, Opera omnia iussu impensaque Leonis XIII edita, vol. 9, Secunda secundae Summae Theologiae [...] cum commentariis Thomae de Vio Caietani (Rome: Typographia Polyglotta, 1897), in q. 122 a. 4, n. 19, p. 484.

39 "Scribere causa sciendi, cognoscendi, docendi, discendi, liberale est opus; causa vero quaestus, servile”. Azor, Institutionum moralium, pars II, lib. I, cap. XXVII, col. 172. A similar position is taken on "transcribere," that is, passively copying a text (ibid., pars II, lib. I, cap. XXVII, col. 173).

40 Azor, Institutionum moralium, pars II, lib. I, cap. XXVII, col. 172.

41 Azor, Institutionum moralium, pars II, lib. I, cap. XXVII, col. 172; see also ibid., pars II, lib. I, cap XXVIII, col. 179: "nullum opus, quod sua natura \& conditione liberale est, in servile transire, eo solum quod quaestus mercedisve gratia fiat”. 
gain, he tries, at least to some extent, to weaken this traditional opinion on the servility of gain per se.

In addressing the same case a few years later, Busenbaum points out that the criterion of lucre is of no importance in defining servility, thereby not actually stating that an activity remains liberal even when done for the sake of lucre. ${ }^{42}$ Its gain, however, is not included as a reason to grant exemption from resting or attending a religious service. ${ }^{43}$

A further evolution may be seen in Liguori. In dealing with the question of writing and studying on holy days, he agrees with Busenbaum in considering lucre as being irrelevant to the definition of servility, because "the intention of the performer of the work cannot change the nature of that work". ${ }^{44} \mathrm{~A}$ few pages later, he follows other authors in going further and labelling the risk of losing high lucre as a "great damage" ("magnum damnum"), thus admitting its pursuit as a valid reason for breaching the obligation of resting and attending services: usually, indeed, "people working for their subsistence rarely have the opportunity to earn such a high lucre, and to them its loss means a great damage". 45 When the lucre at risk is "rare", this also applies, even if only "probably", to fasting. ${ }^{46}$ Evidently, at this point, lucre was no longer held in moral contempt.

\subsection{Grounds for exemption from the obligation of fasting and resting}

From our perspective, a secondary relevant question tackled by our authors is the place of "professional reasons" or "reasons linked to work" in the granting of the right to exemption from the obligations of fasting, resting and attending religious services on certain days.

Exemption from moral obligations on the grounds of general principles usually the idea of urgent necessity (urgens necessitas) and religiousness

42 Busenbaum, Medulla, lib. III, tr. III, dub. I, pp. 126-27: "Impertinens est ad rationem operis servilis, utrum fiat ex lucro an ex recreatione; ex hac, an ista intentione, pia, vana et turpi”.

43 See respectively Busenbaum, Medulla, lib. III, tr. III, dub. II, pp. 128-30, and dub. V, pp. 137-39.

44 Liguori, Theologia, lib. III, tr. III, n. 278 (vol. 1, 554).

45 Liguori, Theologia, lib. III, tr. III, n. 301 (vol. 1, 565); see also n. 332 (vol. 1, 598-99). Among the authors referred to, Martino Bonacina and Niccolò Mazzotta.

46 Liguori, Theologia, lib. III, tr. VI, n. 1046 (vol. 2, 433): “caeterum probabiliter [...] excusant a culpa eos qui, licet ex proprio officio non laborent, tamen laborem aliquem magnum assumunt ob rarum lucrum. Sicut probabiliter non peccant qui ob hujusmodi causam laborant in die festivo". 
(pietas) - had been established centuries earlier by canon law and also applied to the case of resting and fasting: as the ordinary Gloss on the Liber Extra specifies, when commenting on holy days, the rationale is that "necessity and religiousness do not fall under the law". ${ }^{47}$ Our authors naturally follow in this tradition. However, as always when approaching juridical texts - which, notwithstanding the theological topic, these undoubtedly are - it is the interpretation of these fixed general principles, and their application to the specific cases examined, which is key.

Juan Azor, for instance, when dealing with the obligation to fast, interprets these principles and introduces the following, general, "right reasons" ("iustae causae") for exemption: "age, illness or ill health, work [labor], poverty, duty of religiousness [pietatis officium] and the [permission given by the] authority of a superior officer". ${ }^{48}$ The majority of exemptions for the undertaking of professional activities are, naturally, investigated with regard to "work". Azor mentions any "heavy manual labour", which demands the kind of physical effort which can only be made with proper nutrition; therefore, he excludes activities of an intellectual nature and lighter manual work, including lawyers, teachers, notaries, copyists or scribes. ${ }^{49}$ The need for nutrition is discussed not only in consideration of labour carried out on the actual day of fasting, but also with regard to recovering from a previous day's work, and to the proper performance of work on the day after the fasting day. ${ }^{50}$ The permission to do heavy manual

47 Liber Extra 2.9 (De feriis): "nisi necessitas urgeat vel pietas suadeat”, with glo. conquestos specifying: “[...] necessitas vel pietas non est sub lege”; see also Liber Extra 3.46 (De observatione jejuniorum). On the origins of this Canon Law principle, see Franck Roumy, "L'origine et la diffusion de l'adage canonique Necessitas non habet legem (VIII ${ }^{\mathrm{e}}$-XIII ${ }^{\mathrm{e}} \mathrm{s}$.)," in Medieval Church Law and the Origins of the Western Legal Tradition: A Tribute to Kenneth Pennington, ed. Wolfgang P. Müller and Mary E. Sommar (Washington DC: The Catholic University of America Press, 2006), 301-19, and on its application, Mario Ascheri, "Note per la storia dello stato di necessità. La sistemazione canonistica,” Studi Senesi 87 (1975): 7-94.

48 Azor, Institutionum moralium, pars I, lib. VII, cap. XVII, p. 581.

49 Azor, Institutionum moralium, pars I, lib. VII, cap. XVII, p. 583: “An ij qui laborant, cuiusmodi sunt agricolae, et plerique artifices, iustam etiam ieiunij excusationem habeant? Respondeo, eos habere: tales sunt fabri sive ferrarij, sive lignarij, sive caementarij, agrorum cultores, et caeteris huius generis operarij, et artifices; his enim cibus non sufficit semel tantum in die sumptus, ob immodico et nimios corporis labores. [...] Argentarij, aurifices, textores, pelliones, fullones, lanarij, caementarij, pistores, qui item furnariam artem exercent, qui panes coquunt, et similes, meo iudicio excusantur: non autem sartores, pictores, barbitonsores, advocati, scholastici, notarij, scribae, et alij similes, qui multo minus quam supradicti laborant, dum suas artes exercent”.

50 Azor, Institutionum moralium, pars I, lib. VII, cap. XVII, p. 583: "Respondent quidam, arbitrio boni viri esse rem descernendam, ita ut tuto aliquando ieiunium solvant, ne inepti ad 
labour, and thus to abstain from fasting, is granted equally to rich and poor, provided that it is not easily possible to postpone the job. ${ }^{51}$ This attests to an interesting evolution in the application of the concept of "necessity" (necessitas) to our specific case, since previous tradition usually referred to protecting the poor and ensuring that they could - literally - survive, but excluded the rich. ${ }^{52}$ A number of justifications based on the undertaking of "professional activities" are also introduced among the reasons grounded in the duties of religiousness and charity. This applies to ministers of the Church, especially those involved in preaching, and to professors engaged in teaching, provided that their situation does not allow them to undertake the activity conveniently, should they fast. ${ }^{53}$

When Azor comments on the exemption from the obligation to rest or to attend religious services on holy days, he pays equally close attention to the reasons linked to the proper accomplishment of work. Here, other professional figures are considered too. The carrying out of one's public duty - such as governing, military service, and the custody of people or places - which could not be postponed "without severe damage and detriment" entails exemption

labores, et operas in posterum reddantur; aut quia ex labore praeterito nimium defagitati [sic, recte: defatigati] sunt. Probabilis est opinio".

51 Azor, Institutionum moralium, pars I, lib. VII, cap. XVII, p. 583: "Eugenium IIII. concessisse ait potius declarasse: ut opifices, qui laboriosas artes exercent, et agrorum cultores, sive divites sint, sive pauperes, liberi sint à lege ieiunij [...] Addunt etiam, laborem manuum iustam excusationem non dare operarijs, qui opus differre in alium diem commode possunt".

52 In this sense, see for instance Thomas Aquinas, Summa theologiae, IIa-IIae q. 147, art. 4 ad 3, and, more explicitly, Gabriel Biel, Collectorium super IV libros sententiarum (Tübingen: Johann Otmar, for Friedrich Meyberger, 1501), 1. 4, dist. 16, q. 3, art. 1, n. 4, “Tertia causa” (pages not numbered; online at http://reader.digitale-sammlungen.de/de/fs1/object/display/bsb11205529_ 00329.html, accessed on 25.04.2019). Think also of the classic discussion about the case of the starving pauper who steals food in order to survive, Gilles Couvreur, Les pauvres ont-ils des droits? Le vol en cas d'extrême nécessité depuis la Concordia de Gratien (1140) jusqu'à Guillaume d'Auxerre (1231) (Rome: Pontificia Università Gregoriana, 1961). Eugenius IV, in about 1440, admitted this possibility for rich people too, in an unofficial declaration which Azor mentions in his passage quoted in the previous footnote, and so does Liguori (Theologia, lib. III, tr. VI, n. 1042, vol. 2, 430) and other authors, as observed by Vacandard, "Carême (Jeûne du)," 1744.

53 Azor, Institutionum moralium, pars I, lib. VII, cap. XVIII, p. 584: “An pietatis, misericordiae, vel charitatis officium iustam mereatur excusationem à lege ieiunij? Respondeo, si eiusmodi officium aut lege, aut praecepto Maiorum, aut ob communem salutem obeamus, legibus ieiuniorum soluti sumus. Ita divini verbi concionatores, ac similes alij Ecclesiae ministri, liberi sunt à ieiunijs, si munus suum praestare coguntur, et simul commode ieiunium servare nequeunt. Eadem quoque ratione excusantur Magistri, \& Doctores, qui publice alios docent [...]. Si res sit dubia Superioris auctoritate, ieiunij lege solvantur”. 
from these obligations. ${ }^{54}$ Medical professionals are explicitly exempted, on the grounds of both the duty of charity and the necessity to avoid damages; various legal activities are thoroughly investigated, and largely exempted on the same grounds too. ${ }^{55}$

Busenbaum's stance on these aspects is similar to Azor's: he exempts men carrying out hard manual labour from fasting, since the strength of a man who is fasting will usually not be sufficient to adequately undertake such labour. Church ministers, and members of a religious community whose occupation is demanding, or who are in ill health, are granted exemption from fasting on the grounds of the duty of religiousness: lecturers, preceptors, cantors are included here. ${ }^{56}$ In case of necessity or serious risk, physicians and judges are held to be exempted from the sole obligation of resting. ${ }^{57}$

54 As for the exemptions from resting: "Gratia publicae utilitatis, a culpa eximuntur cursores, muliones, agasones, nautae, milites, etiamsi machinas et tormenta bellica parent, ac similiter remiges [...] quando in aliud tempus differri nequeunt sine gravi damno et iactura” (Azor, Institutionum moralium, pars II, lib. I, cap. XXVII, col. 171). The exemption from religious service is granted to a person "qui praeterea gravi aliquo, \& iusto negocio, quod in aliud tempus deferri nequeat, impeditur: quales sunt publici ministri, qui ratione sui muneris, domo egredi, castra dimittere, murorum portas, quas custodiunt, ac tuentur, et vigilias deserere non permittuntur. [...] Tales etiam sunt Magistratus, Senatores ac reliqui primarij viri, qui gravia Reipubli. negocia in aliud temus reijcere commode nequeunt” (ibid., pars I, lib. VII, cap. VII, p. 551).

55 The chapter quoted in note 54 also applies exemption from religious service to medical professionals: "Quales etiam sunt, qui aegrotis inserviunt” (Azor, Institutionum moralium, pars I, lib. VII, cap. VII, p. 551). As for their obligation to rest: "Insuper tuendae, et conservandae valetudinis causa, medici, chirurgi, pharmacopolae, \& aromatatij necessarij culpa liberi sunt" (ibid., pars II, lib. I, cap. XXVII, col. 171); the following chapter also adds: "causa pietatis et charitatis in proximum, opera servilia in die festo, iure permittuntur: hac enim ratione, multa Medici et Chirurgis sunt permissa, ut aegrotis medeantur" (ibid., pars II, lib. I, cap. XXVIII, col. 180). Legal actions are examined closely in the light of the principle that "nisi necessitas urgeat, vel pietas suadeat, in solemnibus ferjis praetermitti debeant” (ibid., pars II, lib. I, cap. XXVII, col. 176).

56 Busenbaum, Medulla, lib. III, tr. VI, dub. II, pp. 280-81: "III.a causa est Labor vel officium, cum quo jejunium non possit consistere; qualis est agricolarum et multorum opificum, ut fabrorum, pistorum, sutorum, etc. [...] Ratio horum omnium est, quia communiter horum vires non sufficiunt ad hujusmodi labores cum jejunio [...] IV.a est pietas, vel maius bonum. Unde excusantur, qui cum jejunio non possunt vacare operibus melioribus, v.g. Concionatores, Praeceptores ordinarii. Confessarii, Cantores, et quotquot opera charitatis, et misericordiae, tam corporalia, quam spiritualia, exercent, etiam ob mercedem, si ea cum jejunio peragere non possunt".

57 Busenbaum, Medulla, lib. III, tr. II, dub. II, pp. 128-29: "Quae causae excusent ab observatione festorum, ob quas opera prohibita liceant? [...] Necessitas propria vel aliena, corporis vel animae; si nimirum sine gravi incommodo, aut detrimento aliquid omitti non possit. Quomodo 
The significant evolution of a couple of points can be detected in Liguori's Theologia. Firstly, when he allows for non-deferrable heavy manual labour to be performed not just by a poor person, but also by the rich, in breach of the obligation to fast, Liguori adds a noteworthy justification: if only the poor are allowed to work on fasting days, the many who do not need to work for their basic subsistence have to interrupt their work, and this inflicts "considerable damage on the State"..$^{58}$

Secondly, physicians, lawyers and judges are now included among the offices (officia) assured exemption from the obligation to fast, and not only to rest, on grounds of religiousness, extending prescriptions previously only addressed to the clergy and to members of religious communities, as we have just seen. The key point, here, is that these professionals have been placed in the same category as ecclesiastical offices and ministers whose duties are fully dealt with in these texts. For Liguori, the explicit aim is to make it possible for judges, lawyers and physicians to completely "satisfy" ("satisfacere") their clients and to balance "the spiritual consumption due to study and intellectual effort". ${ }^{59}$ The concept of "satisfaction" can be understood if we recall the paragraphs on the duties of judges, lawyers and physicians that Liguori, and the tradition of which he was a part, included after having examined the duties of religious and Church ministers in great detail. These paragraphs now require some attention.

excusantur 1. Judicia, quae celeritatem requirunt: v.g. si latro sit fugiturus, nisi tunc capiatur [...] 7. Chirurgi, et pharmacopolae".

58 Liguori, Theologia, lib. III, tr. VI, n. 1042 (vol. 2, 431): "valde interest reipublicae ne causa jejunii operarii intermittant exercere artes quibus ex suo officio incumbunt. Si enim in diebus jejunii tantum pauperes laborare possent sine jejunii obligatione, plures, quibus non est opus actualiter laborare ad se sustentandum, laborem intermitterent: quod certe verteret in notabile reipublicae detrimentum".

59 Liguori, Theologia, lib. III, tr. VI, n. 1048-49 (vol. 2, 435-38): “Quarta causa est pietas. [...] Excusantur concionatores, [...] cantores [...], lectores scientiarum [...]. Excusantur advocati, qui cum jejunio non possent satisfacere suis clientibus, propter studium quo indigent. [...] Idem [...] de judicibus, qui egent studio ad sententias ferendas. Idem [...] de medici et confessariis qui magno indigent studio, ut suis infirmis aut poenitentibus satisfaciant. Hi enim licet non egeant majori cibo, cum labor sit mentis, opus tamen habent cibo frequentiori, ut in eis reparetur spirituum consummatio. [...] Ubi insuper notat quod praedicti professores, nempe lectores, cantores, advocati, medici et confessarii, non per se, sed tantum per accidens a jejunio excusari possunt: nimirum si ratione alicujus gravis circumstantiae suis officiis jejunando non possint satisfacere. [...] Nam ubi labor per se excusat, in dubio praesumptio stat pro exemptione jejunii; e converso, ubi labor non per se, sed per accidens, nempe ob aliquam circumstantiam debilitatis personae vel gravitatem laboris, excusat, in dubio praesumptio stat pro obligatione jejunii". 


\section{The paragraphs on the duties of professionals}

The third chapter (chapters one and two focus on the duties of the religious and the clergy) of the book on the duties of specific states of life in Liguori's Theologia is devoted to lay people and their offices ${ }^{60}$ - and a similar plan can be found in Busenbaum's Medulla ${ }^{61}$ and other works. ${ }^{62}$ As would be expected, given the mixture of the juridical and the moral in these texts, the investigation of legal professionals - judges, lawyers, proctors and notaries, among others is thorough: eight of the ten questions raised ("dubia") in this chapter involve judicial matters. ${ }^{63}$ Two shorter questions finally address the obligations of medical professionals (physicians, surgeons, pharmacists) and of other figures (merchants, book sellers, money-changers, tailors, artisans). ${ }^{64}$

It is worth noting that this plan does not correspond to Azor's Institutiones. After his analysis of the Fourth Commandment and the duty to honour parents, the Spanish Jesuit moves on to the duties of different ecclesiastical and religious functions, and their specific tasks, beneficia and sins. Numerous figures are considered, from the abbot to the preceptor, from the parish priest's assistant to the many officers of the Roman Curia, before the power and duties of the king and nobility are examined; no professional lay figures are addressed in this section, however.

Several cases concerning professional activities, nevertheless, are scrutinised elsewhere in the work - following long-established, juridical and canonical traditions. In particular, the duties and sins of legal professionals are systematically

60 See Liguori, Theologia, lib. IV, cap. III (vol. 2, 625-86), which is entitled "De statu et officio personarum saecularium quarumdam, et praesertim judicialium".

61 See Busenbaum, Medulla, lib. IV, cap. III, pp. 330-60.

62 For instance, a book dealing with the duties of secular people ("personae saeculares") is included by Antonio de Escobar y Mendoza in the 7th part of his Universae theologiae moralis, which explores obligations linked to the state of life, and, as for secular, "communitatum, regiminis urbium, Ministeriorum quorumdam respublica, Medicina, Militia, Agricultura, mercatura, Artificiumque obligationes”. Legal professionals are not included. See de Escobar y Mendoza, Universae theologiae moralis [...] tomus septimus et ultimus Triplex status; ecclesiasticus, religiosus, \& sæcularis (Lyon: Philippe Borde, Laurent Arnaud, Claude Rigaud, and Guillaume Barbier, 1663), 344.

63 In Liguori, Theologia, lib. IV, cap. III, after the examination of the conditions of legitimacy for a trial (legitimum judicium) in the first doubt, the office of the judge (iudex) and the lawyer (advocatus) are analysed in depth in doubts 2 and 3; other figures (referens, secretarius, notarius, procurator) are tackled in doubt 4. Doubts 5 and 6 address the obligations of complainants (accusatores) and witnesses (testes), while doubts 7 and 8 deal with the duties of convicts (rei) and their confessors.

64 Liguori, Theologia, lib. IV, cap. III, dub. IX-X, n. 291-92 (vol. 2, 684-86). 
analysed in the third part of the text, in comments on the Eighth Commandment and mendacity. A full account of this analysis, and of its numerous sources and nuanced solutions, falls outside the scope of this paper. Suffice it to remark that a long series of questions on judges (iudices) is examined in different chapters (discussing their obligation to pursue the truth; possible moral dilemmas between the juridical outcome of a trial and their personal convictions; and the prohibition against their accepting gifts from defendants ${ }^{65}$ ). Another chapter is entitled the "sins of the lawyer"; in it Azor clearly states that lawyers (advocati) must be competent in law and not endorse false statements or witnesses, nor ask for unnecessary delay or suspension in a trial. ${ }^{66}$ The classic, complex prohibition against their defending unjust lawsuits (iniustae causae) is investigated, ${ }^{67}$ together with issues concerning both fees (and the pactum de quota litis in particular ${ }^{68}$ ) and the obligation for lawyers to represent indigent defendants. Azor also alludes to physicians in this context, since their duty of charity similarly obliges them to assist indigent patients. ${ }^{69}$ The physician and the surgeon, together with the lawyer, the counsellor (consiliator), and the procurator (procurator), are also mentioned in the final chapter of the book on the Eighth Commandment, when the author addresses the confidentiality obligation and the duty to keep a (non sacramental, i.e. learned outside the confessional) secret. ${ }^{70}$

65 See Azor, Institutionum moralium, pars III, lib. XIII, cap. XXIII, coll. 1186-90. Similar obligations are stated for instance in the paragraph "de iudiciis" (ibid., pars I, lib. VI, cap. XVIII, pp. 453-54), where this invitation is addressed to the judge: "mendacium fugies, ne a vera flectas". See also ibid., pars I, lib. V, cap. VIII, pp. 341-42.

66 Azor, Institutionum moralium, pars III lib. XIII, cap. XXIX, col. 1214: “qualis debeat esse advocatus, ut idoneus esse censeatur? [...] debet iuris, et legum peritiam habere; unde nemo admittitur ad munus advocandi, nisi quinquennio iuri studuerit, et examinatus fuerit. [...] in primis licite non potest uti falsis instrumentis, aut testibus, aut legibus, aut probationibus, aut allegationibus: nec potest quaerere dilationes non necessarias cum detrimento alterius partis: potest tamen prudenter occultare ea, quae possent iuvare adversarium, vel impedire processum".

67 Azor, Institutionum moralium, pars III, lib. XIII, cap. XXIX, coll. 1214-15. An account of this prohibition and of the history of lawyers' professional ethics can be found in Raffaella Bianchi Riva, L'avvocato non difenda cause ingiuste. Ricerche sulla deontologia forense in età medievale $e$ moderna, vol. 1, Il medioevo (Milan: Giuffrè, 2012). See also Richard H. Helmholz, "Ethical Standars for Advocates and Proctors," in Id., Canon Law and the Law of England (LondonRonceverte: The Hambledon Press, 1987), 41-57.

68 Azor, Institutionum moralium, pars III, lib. XIII, cap. XXIX, coll. 1216-17.

69 Azor, Institutionum moralium, pars III, lib. XIII, cap. XXIX, col. 1216: “an lege misericordiae, et charitatis teneatur advocatus gratis defendere causam pauperis non habentis, unde solvat mercedem? [...] sicut esset peccatum in medico, nisi subvenire aegrotanti, extrame [sic, recte: extreme] laboranti, nec habenti, unde solvat mercedem: sic etiam est peccatum in advocato". 70 Azor, Institutionum moralium, pars III, lib. XIII, cap. XXXI, col. 1221. 
These are not, of course, the only references to medical professionals made in the text, nor the only occasion upon which a parallel between lawyers and physicians is drawn. In the first part of the work, when the key theoretical theme of conscience and moral resolution is under examination, the necessity for physicians to be prudent and to follow accepted scientific opinion ("communis opinio"), whilst avoiding the testing of new therapies unless no generally recognised remedy for a disease is available, is stated. A few lines later, a similar argumentation is applied to lawyers who are deciding whether or not a particular lawsuit is just. ${ }^{71}$ It is intriguing that the obligations of confessors are taken as a model: this is confirmed by the fact that these prescriptions come immediately after a question in which the confessors are studied, and closely follow the same line of reasoning. ${ }^{72}$

When Busenbaum and Liguori argue about the particular prescriptions and sins linked to judges, lawyers, physicians, merchants and other figures, they are clearly adopting questions deeply rooted in tradition, and building upon that tradition, as Azor himself did before them. Unsurprisingly, the questions tackled, and the solutions proposed, are indeed very similar to those to which we have just alluded. The difference lies elsewhere: it is not the actual content that distinguishes their approach from his, but its organisation. It now revolves around professional figures and is anchored within the states of life; different figures are scrutinised with the same approach, and collected together in a specific chapter, which follows those devoted to the clergy and the religious. This modification in the organisation bears witness to a substantial change in conceptualisation, and helps to explain the extent to which the "professional activity" had become a possible state of life - and one which was to increase in importance during the transition towards a bourgeois society. ${ }^{73}$ Needless to say, these remarks by no means suffice to explain the crystallisation of manifold prescriptions around the specific professional figure involved, of different figures around the category of "lay offices", and of these offices around the duties of state. And yet, they are enough to signal that such a crystallisation occurred.

Busenbaum and Liguori both paint portraits of each profession, in which they intertwine the competences, aims and duties particular to each, and impose on legal and medical professionals the obligation to possess the necessary

71 See Azor, Institutionum moralium, pars I, lib. II, cap. XVII, p. 117, and, for lawyers, 117-18. On the same subject, see also the parallel between lawyer and physician drawn ibid., pars III, lib. XIII, cap. XXIX, col. 1215.

72 See Azor, Institutionum moralium, pars I, lib. II, cap. XVII, pp. 116-17.

73 See Faitini, Il lavoro come professione, 276-78. 
knowledge and operate with diligence to foster justice and health. ${ }^{74}$ These detailed portraits find their place alongside those of the religious and ecclesiastical offices and are, to some extent, modelled upon them. It is to these descriptions that one must turn in order to understand what the "satisfaction" of the client or the patient is, and to ground exceptions from general moral duties. Each activity appears to imply specific moral duties (diligence and competence, among others), which have to be balanced with general duties, such as those imposed by the Decalogue: the debate on the questions of resting and fasting provides us with remarkable examples with regard to this balancing. In this portrait gallery, the carrying out of a professional activity and the balanced fulfilment of specific and general duties combine explicitly, and directly contribute to defining the social and ecclesiastical status of the performer.

\section{Conclusion}

In making such observations, and developing their organised exposition, these texts reveal the extent to which they are linked to the Christian tradition of thought on the duties of the Church ministers, and to subsequent thought on the duties of the states of life, as recalled above. More exactly, these texts reveal how this tradition is extended and applied to a wider range of worldly, lay,

74 Busenbaum's discussion on medical professionals, quoted without comment by Liguori, starts by observing that they "tenentur ij imprimis, quando tale officium petunt, vel suscipiunt, sub gravi obligatione, sufficientem habere scientiam, sive peritiam” (Medulla, lib. IV, cap. III, dub. IX p. 357); it goes on to remark that physicians commit sins "si absque sufficienti peritia gravem morbum curare tentet", pharmacists commit sins "si rudis \& ignarus munus exerceat" or "sine arte, vel diligentia, medicamenta conficiat", and surgeons do the same if they operate "sine scientia \& peritia sufficienti" (ibid., lib. IV, cap. III, dub. IX, p. 358). As for legal professionals, Busenbaum immediately states that from the judge "requiritur scientia", that is, "scire ea quae pertinent ad proprium officium, et sine quorum cognitione munus suum et officium exercere non potest” (ibid., lib. IV, cap. III, dub. II, p. 331); lawyers need to comply with "scientiam convenientem, justitiam causae, fidelitatem et pretium justum" (ibid., lib. IV, cap. III, dub. III, p. 340). Analysing other legal figures (referens, secretarius, notarius, procurator), he observes that "tenentur scire ea quae ad suum officium spectant, debitamque diligentiam adhibere, praestando omnia necessaria, terminos justos petendo, et appellando, cum fuerit necessarium" (ibid., lib. IV, cap. III, dub. IV, p. 345). Comparable phrases can be found in Liguori's discussion on legal professionals (Theologia, lib. IV, c. III, dub. I-V, vol. 2, 625-64), which, after quoting Busenbaum's passages, considerably expands on them; in both authors, expressions such as "defectum studii”, "incuria”, "imperitia”, "negligentia”, "non ideoneus/ dignus esse", "differire causarum expeditionem", “dilatio superflua” occur repeatedly in describing professional sins. 
activities, which are to be performed in compliance with Christian morality and its commandments, but also have specific obligations. As part of this balancing act, on the one hand, religious duties were interpreted, and exemptions granted, in view of particular professional needs; on the other, specific profiles of professionals and their duties, based on ecclesiastical models, were constructed. In this dialectical process, Christian morality was modified by, and adapted to, worldly activities and professional practice, but - equally and simultaneously it actively shaped these activities and this practice.

It is worth noting that the emphasis on the dimension of duty, and the association of professional figures with the states of life, reflects the fact that a profession was still regarded as a status to declare and fulfil, and not as an activity to perform. Nevertheless, the increasing importance given to lucre attests to the profession's becoming an economic activity, entered into by contract and performed in order to earn an income; as does the emphasis placed on the necessity to preserve energy to duly accomplish the task, and to avoid damages to the State. Here, one touches upon the intertwining of the two roots lying at the heart of the modern experience of the profession, which makes a socio-political status essentially - and even exclusively dependent on the accomplishment of an economic-acquisitive activity.

This analysis hints towards the hypothesis that there is a particular, ecclesiastical model behind the secular professions and their professional ethics; and that this model extends its influence beyond the clerk or public offices within state bureaucracy, upon which historiography has so far laid greatest emphasis. The classical and the Christian tradition de officiis undoubtedly combined in the practice of officeholding in early modern European states. However, the impact of this combined tradition (and its practical realisation) seem to have been even more far-reaching, in that it involved the actual figure of the professional, and the experience of the profession as such, outside the purely statal sphere. And, notwithstanding a clear continuity with an inherited, previous tradition, the gradual transposition of the rhetoric of office and the states of life (also) to the economic and professional sphere has to be acknowledged.

From a broader perspective, the provided account suggests that the theological theorisation on the states of life (and corresponding practices) is among the reasons why social position, the carrying out of an economic activity, and the fulfilment of a moral and legal duty, have become inextricably linked in Western economic and socio-political rationality. This is the multifaceted link ideally embodied in our concept of the profession - and in the highly valued experience it encapsulates. These post-Tridentine sources may thus help to complete Weber's interpretation, by drawing additional maps for the historical atlas of modernity and its iron cage. And within these maps, a specific model for the profession can be clearly perceived. 
Acknowledgements: I wish to thank Dante Fedele, Michele Nicoletti, Knud Haakonssen, Martina Roesner, Nathan Alexander, Camilla Smith, and two anonymous reviewers for their comments on earlier drafts of this article.

Funding: This work was supported by the European Union's Horizon 2020 research and innovation programme under the Marie Skłodowska-Curie grant agreement No 665958. 